\title{
淀川下流の水道の水源としての琵琶湖*
}

\section{1. 淀川水系について}

淀川水系は日本最大の湖である琵琶湖を主な水源と し，大津市から瀬田川となって南流し、天ヶ瀬ダムを 経て, 宇治川となり西流し、山崎地点で左岸に木津川, 右岸に桂川を合流して，大阪平野を西南に流孔，大阪 湾に注いでいる。

淀川流域を気象学的に分類すると, 雨量の少ない瀬 戸内海気候区に属する下流部，台風による雨量の多い 紀伊山地に連なる木津川上流部，降雪量の多い日本海 岸気候区に入る琵琶湖北部, 前線性雨量の多い桂川上 流部の 4 つに分類できる。このため, 冬期, 梅雨期, 台風期にしたがい, 互い違いに流況の欠点を補い合っ ている。なかでも, 琵琶湖は天然の大貯水池となり, 瀬田川洗堰の放流量調節によって, 淀川本川は他の河 川に比較して, 洪水流量が小さく, 渴水流量が多く, 流況の安定した河川となっている。

淀川本川に扮ける年間平均流量の約 $63.7 \%$ を宇治川 流量, 木津川流量が約 $13.6 \%$, 桂川流量が約 $22.6 \%$ を 占めている。宇治川からの流量の割合が高く, 渴水に なれば, ますます宇治川流量の占める度合が高くなり， 琵琶湖放流量の影響が非常に強くなる。

\section{2。琵琶湖の富栄養化と淀川下流水道}

約 400 万年の歴史を持つ琵琶湖は, 長く貧栄養湖とし て知られ，非常にきれいな水を湛えてきた。大阪市水 道局では大津市三井寺沖 (京都疏水沖約 $400 \mathrm{~m}$ ) 飞扔い て, 昭和 3 年から戦時中の昭和 19 年を除き水源調査の 定点の 1 つとして, 調査を続けている。このらち, 色

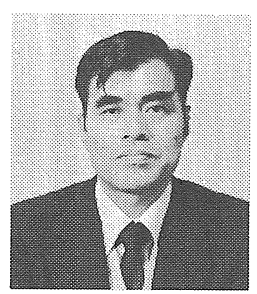

Tadashi Kita

昭和33年 大阪市水道局水質試験所

52 年 同局工務部主幹

55 年 同部水質試験所長

* The Lake Biwa as a Source of Tap Water in the Downstream Area of the Yodo River, 昭和59年 4 月27日 受理
度及び過マンガン酸カリウム消費量の経年変化を図 1 に示す。

昭和 30 年代から, 琵琶湖への栄養塩類や有機物等の 流入が増加し，富栄養化の傾向が見られるようになっ てきた。それまでは，プランクトンは少なく，透明度 も大きかったが，従来北湖の優占種であった珪藻類の Melosira solide に代わって, 従来出現していたが量的 に少なかった緑藻類のClosterium aciculare var, sulpronum が，昭和33年頃から急に著しい増加を始め た。次いで昭和 36 年頃から, 同じく緑藻類のStaurastrum dorsidentiterum var. ornatum が先の $C$. aciculare var.に代わって急に増殖した。

また，琵琶湖大橋より以南の南湖に扔いて発生した 珪藻類の Melosira granulata や藍藻類の Anabaena $s p$.によって淀川下流の水道に抢いても, 濾過池の閉塞 障害を起こした。

さらに, 昭和 44 年から, 南湖で藍藻類のPhormidium tenue の増殖によるカビ臭が，京都疏水から取水する 京都市水道で感じられ，その時は，大津市や他の淀川 から取水する水道では異臭が生じなかった。しかし， 翌45年から 47 年には，これが淀川下流まで影響するよ らになった。その後しばらく, 小規模あるいは狭い地 域のカビ臭発生が続いたが，淀川下流まで感じること なく小康状態を得た。しかしながら，昭和56年夏季に 藍藻類の Anabaena macrospora に上るカビ臭に見舞 われた。昭和57, 58年には, 再び P. tenue によるカビ 臭被害を，淀川下流も受けた。P. tenueからは2 -Methyl-iso-borneol, A. macrospora からは Geosmin をそれぞれ産生して抢り，これら2物質は欧米 でカビ臭原因物質として報告されているものである。 最近, ガスクロマトグラフ・質量分析装置によってng/ l程度まで測定可能となってきた。

カビ臭の発生は毎年短期であって, 最も経済的で効 果的な粉末活性炭注入処理を, 大阪市水道では柴島浄 水場（急速滤過系のみ，緩速濾過系は滤過過程でカビ 臭を除去できたが，昭和 49 年 9 月で緩速系は停止）及 び庭窪浄水場（すべて急速系）に打いて実施してきた。

大阪市豊野浄水場は, 山崎合流点直下の楠葉淀川左 岸で，木津川の水を和もに取水しているため，琵琶湖 の異臭の影響はなかった。ただし, 昭和55年 6 月には, 


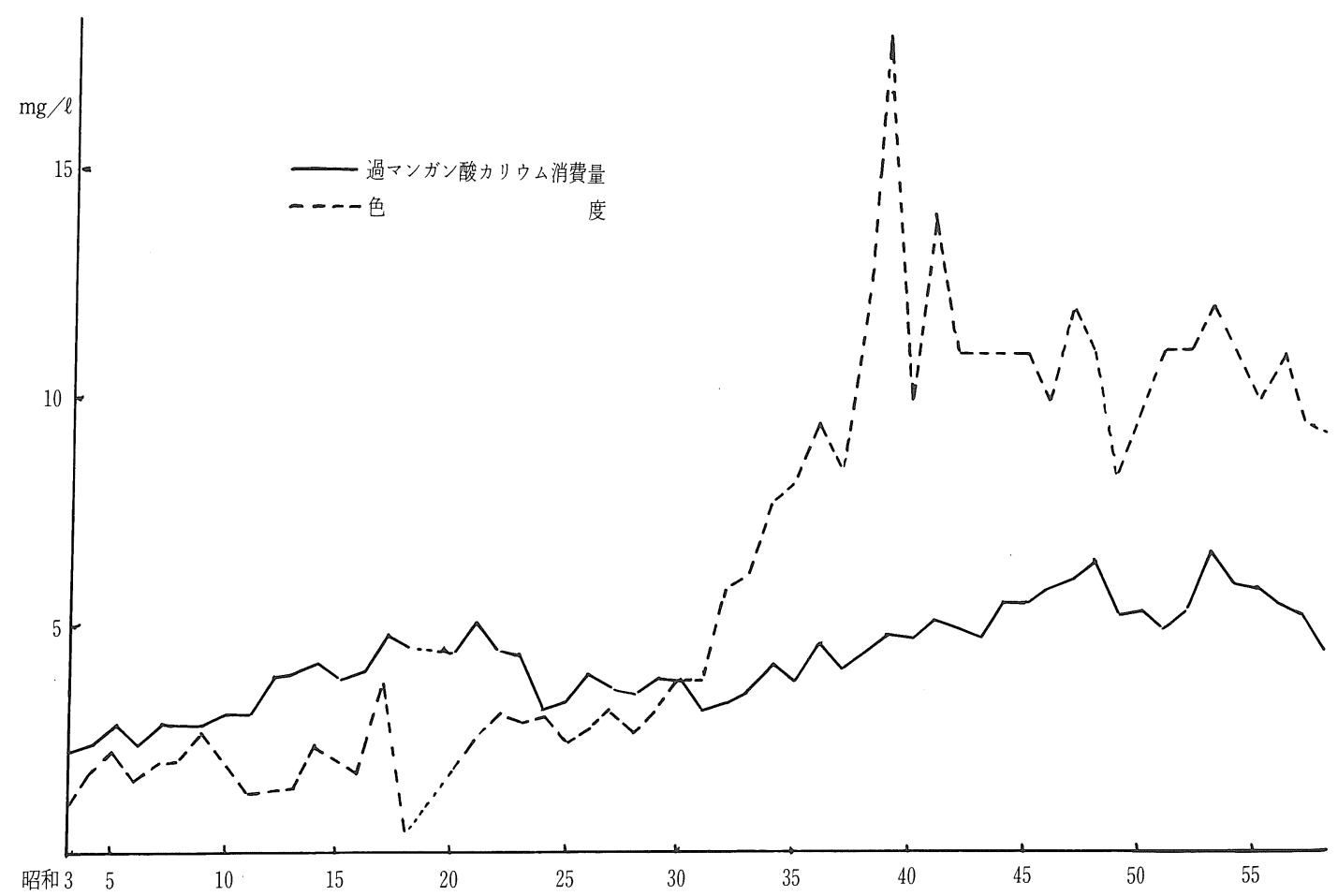

図 1 琵琶湖三井寺沖の過マンガン酸カリウム消費量 $(\mathrm{mg} / \mathrm{l})$ 及び色度の経年変化

木津川上流の室生ダムにおけるP.tenue によるカビ 臭が, 室生ダムと, その下流の高山ダムの降雨後の大 量放流によって, 楠葉左岸に影響を与えた。しかし, 幸い, そのカビ臭の程度は弱く, 粉末活性炭処理をす るには至らなかった。この際は, 楠葉より下流の各水 道には影響が及ばなかった。

\section{3. 淀川水質の経年変化}

\section{1 底生生物から見た, 水質経年変化}

常時川底に生活している底生生物によって, 淀川水 質を 10 年ごとに調査した結果を図 2 に示寸。きれいな 方から貧腐水性, $\beta$ 一中腐水性, $\alpha$ 一中腐水性となり, 最も污濁した水にも耐える生物の生活する地域が強腐 水性である。

昭和 30 年には, 琵琶湖からの宇治川ならびに木津川 は，貧腐水性であるが，京都市の家庭下水及び工場排 水を受ける桂川は強腐水性である。三川合流後, 水は すぐには混ざらず，徐々に混合するので，桂川の流入 する右岸は強腐水性であり, 左岸は, 鳥飼付近まで $\beta$ 一中腐水性である。下流は左右両岸とも $\alpha$ 一中腐水性 である。

その後, 昭和 40 年には, 琵琶湖からの宇治川上流の 水は貧腐水性水域であるが, 戦後の経済復興, 発展が
あり, この頃は, まだ下水道, 工場排水処理が未整備 であったため, 京都疏水, 東高瀬川の右岸への流入に よって宇治川右岸は強腐水性になる。さらに, 桂川の 水質悪化から鳥飼大橋付近をで右岸は強腐水性を示 す。左岸においては, 右岸の影響と三川合流後の枚方 地区からの左岸への污濁の流入があって, 枚方大橋付 近から $\beta$ 一中腐水性から $\alpha$ 一中腐水性に変わってい る。

昭和 50,51 年の調査では, 琵琶湖の富栄養化によっ て, 宇治地点に批ける宇治川が以前の貧腐水性から $\beta$ 一中腐水性水域になっている。一方, 京都市に抢ける 下水道の拡充, 工場排水処理の整備によって, 伏見地 区や桂川の水質が改善され, 本川に抢ける強腐水性水 域は著しく縮少した。

\section{1 大阪市水道局原水水質の経年変化}

大阪市水道局は山崎の三川合流点直下の楠葉左岸で 取水する豊野浄水場, 次いで約 $17 \mathrm{~km}$ 下流の鳥飼大橋 左岸から取水している庭寉浄水場, さらに約 $6 \mathrm{~km}$ 下 流で, 淀川大堰の上流約 $1 \mathrm{~km}$ の右岸に取水塔のある 柴島浄水場の 3 浄水場で浄水処理を行っている。 3 浄 水場原水の生物化学的酸素要求量 $(\mathrm{BOD})$, アンモニア 性窒素及び淀川流量の年度別平均值の経年変化を図 3 〜 5 に示す。 


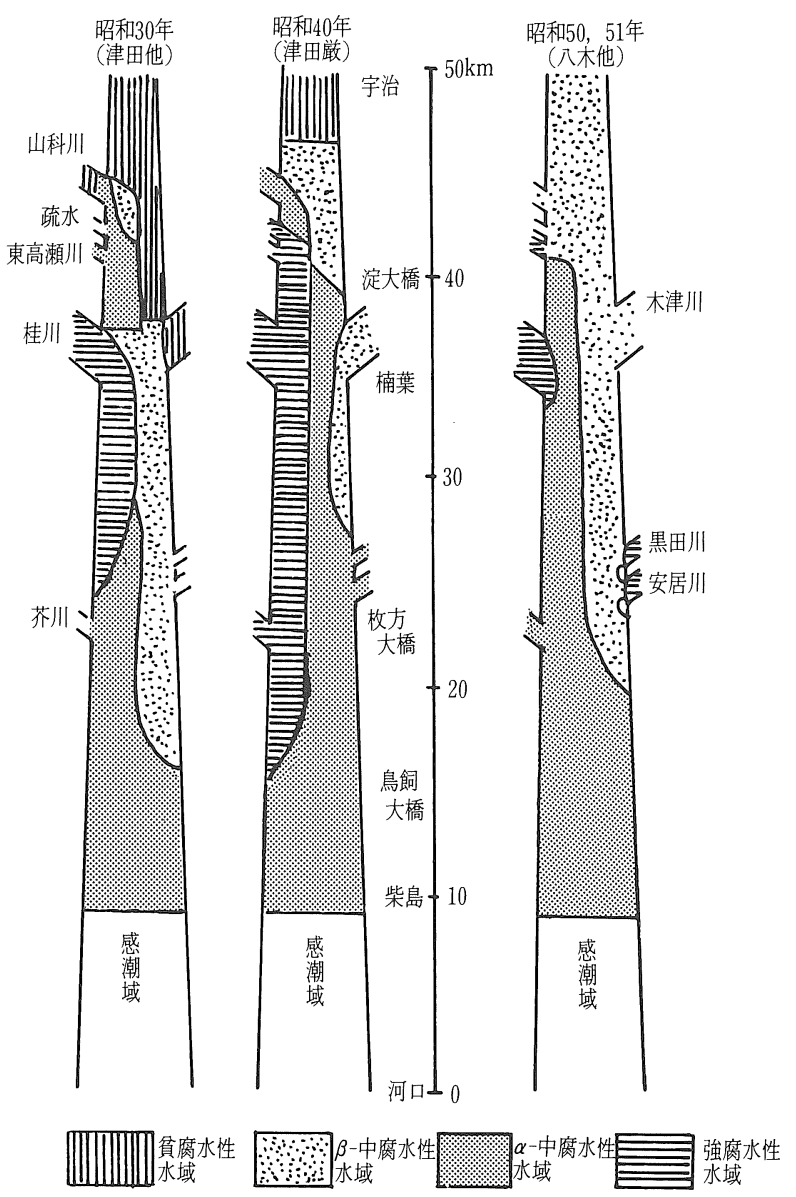

図 2 淀川の生物学的水質污染図

柴島浄原水の BOD の経年変化を見ると, 京都市の 都市下水, 工場排水を受ける桂川が右岸に流入するの で，宇治川の水による混合希釈が徐々に行われるが， 昭和 30 年頃は, 鳥飼大橋左岸の庭䆶原水に比べ, 水質 が悪かった。さらに, 経済発展による污水流入の増加 によって急に悪化し, 昭和38年には BOD で, 年平均值 でこれまで最高の $7.4 \mathrm{mg} / \ell$ を示した。しかし，その後水 質污濁防止法の規制を受けて工場排水が処理されるよ らになった。また, 下水道が整備され, 活性污泥法に よって BOD は減少し, 最近は, ほぼ横ばい状態であ る。一方現在の活性污泥による下水処理では, 十分除 けないアンモニア性窒素は, やや増加の傾向にあり,

特に冬季の低水温時での増加が著しい。

庭窪鳥飼大橋左岸の昭和 32 年頃は, 京都市の排水の 影響が左岸には少なく, 柴島原水と比較して, き机い な水質であった。しかし，右岸への京都からの污濁流 入の増加と, 三川合流後の枚方地区の開発が進んだた

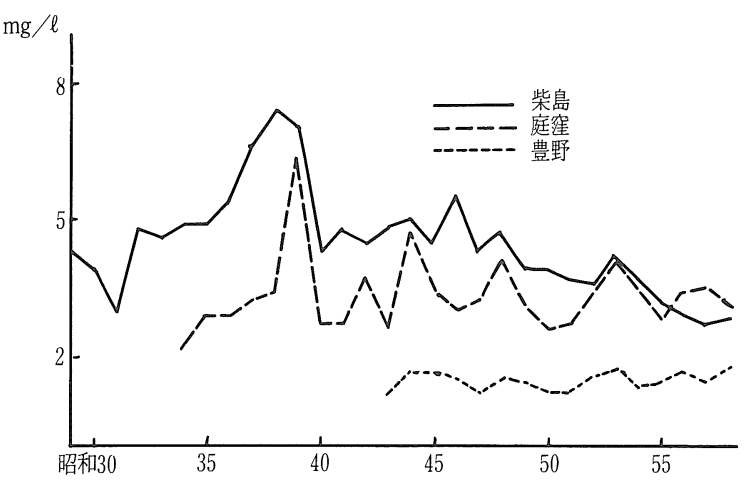

図 3 大阪市水道局原水の $\mathrm{BOD}$ の経年変化

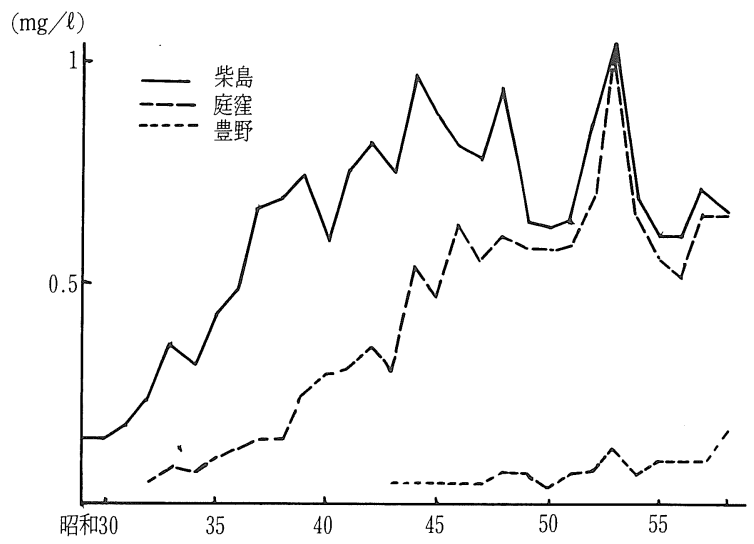

図 4 大阪市水道局原水のアンモニア性窒素の経年变化

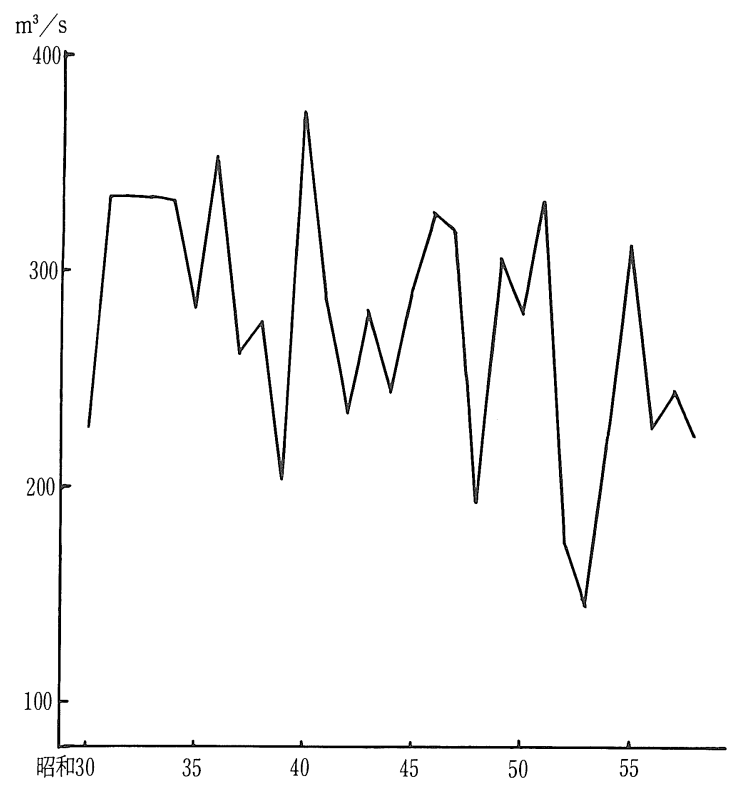

図 5 淀川の年度別平均流量（枚方大橋） 
めに，急激に悪くなった。さらに，昭和39年の淀川は 渴水であって，現在までの BOD のなかで最高の 6.4 $\mathrm{mg} / \ell$ を示したが，翌 40 年は淀川流量が増えて BOD 值 は減少した。その後, BOD については, 医ぼ横ばいの 状態で，昭和53年の渴水時には，少し上昇している。 また, 最近の鳥飼大橋地点に抢いては, 左右両岸の水 質の差がほとんどなくなっている。アンモニア性窒素 については, 柴島に比べ増加が著しく, 現在では, 柴 島とほぼ同じ值を示し, 特に渴水の昭和 53 年には平均 值で $1.01 \mathrm{mg} / \ell$ を示した。

豊野浄水場の楠葉左岸原水は，主に木津川の水を取 水していて，比較的きれいな水であるが，最近，木津 川上流の人口の増加によって, アンモニア性窒素が, やや増加の傾向にある。

\section{5.まと め}

淀川本流に和ける琵琶湖，宇治川の水の占める割合 は 6 割を超え, 渴水時には約 7 割になる。従って淀川 下流水質に与兄る琵琶湖の影響は大きい。従って, 滋 賀県に抢ける下水道の整備等によって, 琵琶湖の水質 が改善されることを望むものである。

下流水道によって, 現在最も重要な問題は, カビ臭 問題であり，大阪市水道局では，カビ臭物質を含む微 量有機物の対策について, 上り有効で, 経済的な浄水 処理について調査検討中である。しかし，根本的な対 策は琵琶湖富栄養化を防止することにあると考光る。 そこで, 既に施行されている滋賀県の琵琶湖富栄養化 防止条例に加光，今国会に再提案されている湖沼水質 保全特別措置法の成立によって, リン，窒素，有機物 等の流入が削減され，水質が良くなることを期待する ものである。

\section{せせらぎ 元}

\section{ドイッの水, ビール, ワイン}

今年の 2 月前半, フランス, ドイッに出張する機会 を得た。排水課徵金という制度に興味を持っていたこ ともあり，フランスではセーヌ・ノルマンディ流域財 団とアッシュ下水処理場, ドイッではノルトライン。 ウェストファーレン州の上下水庁 (Landesamt für Wasser und Abfall) とエムッシャー川水管理事業団 (Emscher genossenschaft) と河口の下水処理場など を訪問した。汪んの半月汪どの“扎上りさん”でした が，ドイッの思い出に筆を走らせてみます。

ジュッセルドルフでは, 大阪市からジェトロに出て いる片木淳さんにさんざん敃世話になったのですが， 彼と州の上下水庁次長のハーバード・マッシング博士 を訪ねた時のことです。今年の 2 月のドイッは日本と まるで逆の暖冬で，私も汗ばんで扣りました。それで 部屋に入るなり，「まずは水を 1 杯所望」，とやったわ けですが，先方は本音とウイットを取り違えてくれま して,「さすが!水のことで来られたので最初に水です ね」，で，大笑いになりました。それはともかく，秘書 嬢が運んできたのはガス入りの水, つまり炭酸水でし た。日本ならここで，「ああらまかった!」，の感嘆詞 が出るところですが，サラリとした感じがなく，少し 重かったわけですね。「どらも」までで，ウイットに返
す言葉を見つけられませんでした。

次に例のビールですが，ピルスといらのはまだ良い のですが，一般的なダンクレスというのですか，わが 国のとは全く違って，テレビの宣伝のようにグーッと 「ゴックンゴックン」といらわけにはいきません。 ちょっと時間をかけて，何回かに分けての飲み方でや りますね。これも素材である水のせいなのでしょらか。 それとも，私の喉が日本人的すぎるのでしょらか。

どらも先方の悪口を言っているようで気がひけるの で，今度は汪める立場になってのことにしましょう。 ワインのことです。1晚招かれてマッシングさんと ジュッセルドルフのアルテシュタットを片言英語を介 してリキュール酒, ビール，それにワインのハシゴを やりました。彼がその間，多弁にロにしたことの繰り 返しは，「ワイン イズ グッド」でした。さべなるか なであります。こればかりはカブトを脱がざるを得ま せんでした。

商売柄, 水のことばかりで終始してしまいましたが, せめて駆け足ではなく，何年かに一度はゆっくりと旅 をして水を味わい，わが日本をふり返るのも良いもの だと，忘れ去ることに反比例して想いがつのっている 昨今であります。

（神奈川県水質保全課長 長崎義一） 